Keywords: $M C U, A R P, I S D P$

Retention: Permanent

\title{
Results of Analyses of Macrobatch 3 Decontaminated Salt Solution (DSS) Coalescer and Pre-filters
}

\author{
T. B. Peters \\ F. F. Fondeur \\ S. D. Fink
}

June 2012

Savannah River National Laboratory Savannah River Nuclear Solutions

Aiken, SC 29808

Prepared for the U.S. Department of Energy under

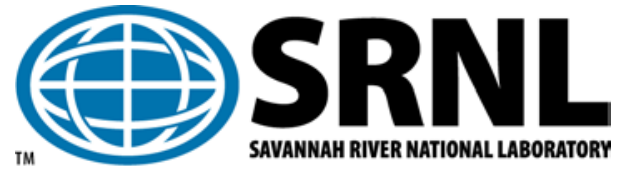
contract number DE-AC09-08SR22470. 
SRNL-STI-2011-00513

Revision 0

\section{DISCLAIMER}

This work was prepared under an agreement with and funded by the U.S. Government. Neither the U.S. Government or its employees, nor any of its contractors, subcontractors or their employees, makes any express or implied:

1. warranty or assumes any legal liability for the accuracy, completeness, or for the use or results of such use of any information, product, or process disclosed; or

2. representation that such use or results of such use would not infringe privately owned rights; or

3. endorsement or recommendation of any specifically identified commercial product, process, or service.

Any views and opinions of authors expressed in this work do not necessarily state or reflect those of the United States Government, or its contractors, or subcontractors.

\section{Printed in the United States of America}

Prepared for

U.S. Department of Energy 


\section{REVIEWS AND APPROVALS}

\section{AUTHORS:}

T. B. Peters, Author, SRNL/SASP

Date

F. F. Fondeur, Co-author, SRNL/SASP

Date

TECHNICAL REVIEW:

C. A. Nash, Technical Reviewer, SRNL/ACP

Date

APPROVAL:

S. D. Fink, SRNL/SASP, Manager

Date

S. L. Marra, SRNL/E\&CPT Research Programs, Manager

Date

D. J. Martin, Manager, H Tank Farm Engineering

Date 


\section{EXECUTIVE SUMMARY}

SRNL analyzed the pre-filter and Decontamination Salt Solution (DSS) coalescer from MCU by several analytical methods. The results of these analyses indicate that overall there is light to moderate solids fouling of both the coalescer and pre-filter elements. The majority of the solids contain aluminum, sodium, silicon, and titanium, in oxide and/or hydroxide forms that we have noted before. The titanium is presumably precipitated from leached, dissolved monosodium titanate (MST) or fines from MST at ARP, and the quantity we find is significantly greater than in the past.

A parallel report discusses potential causes for the increased leaching rate of MST, showing that increases in free hydroxide concentration of the feed solutions and of chemical cleaning solutions lead to faster leaching of titanium. 


\title{
LIST OF ABBREVIATIONS
}

\author{
ARP - Actinide Removal Process \\ DSS - Decontaminated Salt Solution \\ DSSHT - Decontaminated Salt Solution Hold Tank \\ FTIR - Fourier Transform Infra-Red spectroscopy \\ ICPES - inductively-coupled plasma emission spectroscopy \\ MCU - Modular Caustic-Side Solvent Extraction Unit \\ MST - monosodium titanate \\ SE - Strip Effluent \\ SEHT - Strip Effluent Hold Tank \\ SEM - Scanning Electron Microscopy \\ SRNL - Savannah River National Laboratory \\ SSRT - Salt Solution Receipt Tank \\ XRD - X-Ray Diffraction
}




\subsection{Introduction}

To reduce solids fouling of the Decontaminated Salt Solution (DSS) coalescer, a prefilter bundle was added to the system during the outage between the processing of Salt Batch 1 and Salt Batch 2 (September 2008 - January 2008). This pre-filter was in place throughout the processing of Salt Batch 2 and into the first half of Salt Batch 3. The DSS coalescer element was replaced between Salt Batch 2 and Salt Batch 3. After $~ 8$ months of use, a gradual pressure-drop increase to 4 psi, coupled with an increase in Isopar ${ }^{\circledR} \mathrm{L}$ carryover variability prompted Operations personnel to replace the DSS coalescer. After another two months of use, a gradual pressure-drop increase in the DSS pre-filter bundle to 26 psi prompted another replaced by Operations ( February 12, 2011). Both the coalescer and the three pre-filter elements were sent to SRNL for analysis. The pre-filter bundle consisted of three coalescer tubes, each identical in type and material to the coalescer. The pre-filter is mounted in a horizontal parallel triangular configuration with three coalescer tubes in a common housing. Both the pre-filter and coalescer are made primarily of polyphenylene sulfide and were drained of liquids in the facility before removal but no significant effort was made to chemical clean the elements.

\subsection{Experimental Procedure}

When the items arrived at SRNL, the researchers performed a visual study to look for obvious defects or plugging.

Personnel then cut 1" wide rings from each pre-filter and from the coalescer element. These rings were each completely immersed in $200 \mathrm{~mL}$ of $3 \mathrm{M}$ nitric acid for $\sim 1$ month at room temperature. No agitation was applied other than when the sample was initially immersed. Samples from the leachates were removed at 1, 7, 14, and 28 days. The leachate samples were analyzed by Inductively Coupled Plasma Emission Spectroscopy (ICPES).

Samples of unleached material were also analyzed by X-Ray Diffraction (XRD), Scanning Electron Microscopy (SEM), Fourier Transform Infra-Red (FTIR) spectroscopy, and visual microscopy.

\subsection{Results and Discussion}

3.1 Visual Observations As-received, the coalescer element (identified as " $\mathrm{A}$ " for this report) was not heavily loaded with solids and had minimal discoloration. No loose solids or free liquids were associated with this element. See Figure 1. 


\section{Figure 1. DSS Coalescer Element}

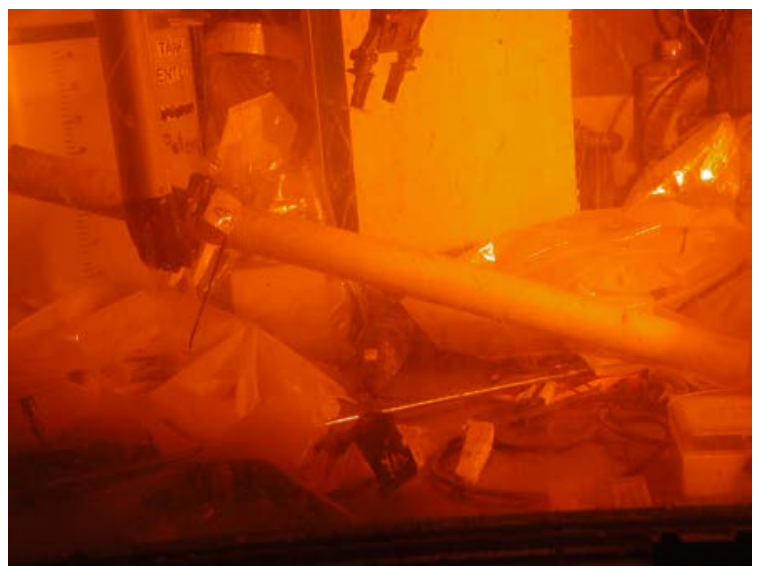

The outer tube for the pre-filter elements contained an estimated 20-30 mL of free liquid that was lost upon opening. The three elements (identified as " $B$ ", “ $C$ ”, and " $D$ " for this report) showed varying amounts of discoloration; possibly indicative of non-uniform flow pattern in housing. Element $\mathrm{C}$ showed some marked discoloration on one narrow portion.

\section{Figure 2. DSS Pre-Filter Elements}

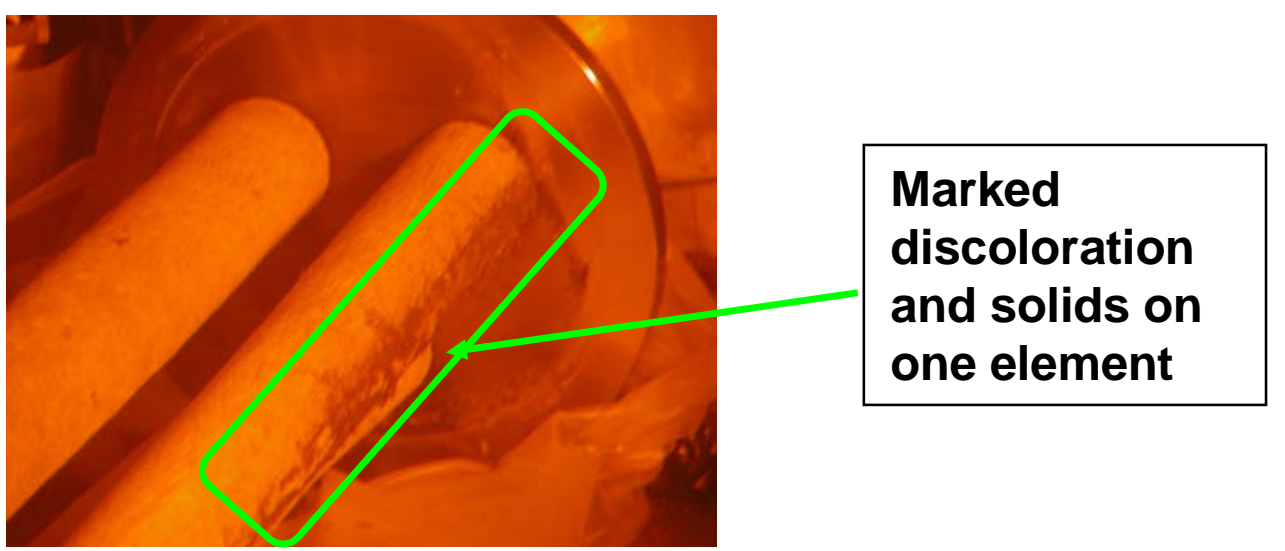

SRNL is uncertain why solids preferentially collected only on a single pre-filter element and only on "dead" end (i.e., the end of the element away from the flow inlet) of that element.

3.2 Leaching Studies Samples from the leaching studies were analyzed by ICPES (see Tables 1-4). A review of this data provides several immediate points of interest.

Effect of Leaching Time: The concentration of the analytes in the leachate samples for each element increases only slightly over the time period of 1 to 28 days, with the notable exception of silicon. 
Table 1. 1-Day ICPES Results for the Pre-filter and Coalescer Elements

\begin{tabular}{|c|c|c|c|c|c|}
\hline \multirow{2}{*}{ Analyte } & \multicolumn{4}{|c|}{ 1-Day ICPES Sample Results (mg/L) } & \multirow{2}{*}{$\begin{array}{c}\text { Source } \\
\text { Material } \\
(\mathrm{mg} / \mathrm{L})\end{array}$} \\
\hline & A (coalescer) & B (pre-filter) & C (pre-filter) & D (pre-filter) & \\
\hline $\mathrm{Ag}$ & $<0.214$ & $<0.214$ & $<0.214$ & $<0.214$ & $<2.14$ \\
\hline $\mathrm{Al}$ & 990 & 2080 & 2170 & 1970 & 5290 \\
\hline $\mathrm{B}$ & 0.338 & 1.07 & 1.24 & 1.01 & 82.6 \\
\hline $\mathrm{Ba}$ & 0.985 & 1.54 & 1.93 & 1.57 & $<0.59$ \\
\hline $\mathrm{Be}$ & $<0.011$ & $<0.011$ & $<0.011$ & $<0.011$ & $<0.7$ \\
\hline $\mathrm{Ca}$ & 11.3 & 32.6 & 45.7 & 33.1 & 2.27 \\
\hline $\mathrm{Cd}$ & 3.36 & 4.79 & 6.13 & 4.83 & 1.17 \\
\hline $\mathrm{Ce}$ & $<0.66$ & $<0.66$ & $<0.66$ & $<0.66$ & $<6.6$ \\
\hline Co & 0.151 & 0.163 & 0.225 & 0.137 & \\
\hline $\mathrm{Cr}$ & 5.36 & 5.9 & 7.62 & 5.89 & 71.6 \\
\hline $\mathrm{Cu}$ & 2.32 & 2.74 & 4.18 & 2.48 & 1.68 \\
\hline $\mathrm{Fe}$ & 51.9 & 54.6 & 73.3 & 55.6 & 12.2 \\
\hline Gd & $<0.212$ & $<0.212$ & $<0.212$ & $<0.212$ & $<2.12$ \\
\hline $\mathrm{K}$ & $<2.00$ & 4.45 & 5.52 & 3.25 & 480 \\
\hline $\mathrm{La}$ & $<0.100$ & $<0.100$ & $<0.100$ & $<0.100$ & $<1$ \\
\hline $\mathrm{Li}$ & 2.25 & 4.3 & 6.79 & 4.4 & 25.6 \\
\hline $\mathrm{Mg}$ & 9.95 & 13.3 & 18.2 & 13.6 & $<0.25$ \\
\hline $\mathrm{Mn}$ & 0.954 & 1.02 & 1.34 & 0.968 & 0.88 \\
\hline Mo & $<0.427$ & $<0.427$ & $<0.427$ & $<0.427$ & 8.47 \\
\hline $\mathrm{Na}$ & 1310 & 3330 & 3530 & 3170 & 157000 \\
\hline $\mathrm{Ni}$ & 20.4 & 17.7 & 24.1 & 18.2 & $<2.35$ \\
\hline $\mathrm{P}$ & $<8.49$ & $<8.49$ & $<8.49$ & $<8.49$ & 272 \\
\hline $\mathrm{Pb}$ & $<0.731$ & $<0.731$ & $<0.731$ & $<0.731$ & $<7.31$ \\
\hline S & $<75.0$ & $<75.0$ & $<75.0$ & $<75.0$ & 2410 \\
\hline $\mathrm{Sb}$ & $<0.688$ & $<0.688$ & $<0.688$ & 0.886 & $<10.4$ \\
\hline $\mathrm{Si}$ & 787 & 1540 & 1610 & 1440 & 168 \\
\hline Sn & $<6.88$ & $<6.88$ & $<6.88$ & $<6.88$ & $<4.29$ \\
\hline $\mathrm{Sr}$ & 0.104 & 0.205 & 0.267 & 0.201 & $<0.08$ \\
\hline Th & $<2.36$ & $<2.36$ & $<2.36$ & $<2.36$ & \\
\hline $\mathrm{Ti}$ & 322 & 605 & 782 & 616 & $<0.17$ \\
\hline $\mathrm{U}$ & 20.3 & 41.2 & 51 & 41.8 & $<44.5$ \\
\hline V & 0.059 & 0.119 & 0.162 & 0.124 & $<0.52$ \\
\hline $\mathrm{Zn}$ & 4.93 & 4.71 & 6.16 & 4.46 & 6.5 \\
\hline $\mathrm{Zr}$ & 0.456 & 0.831 & 1.03 & 0.859 & $<0.89$ \\
\hline
\end{tabular}

The analytical uncertainty for the ICPES samples is $10 \%$. 
Table 2. 7-Day ICPES Results for the Pre-filter and Coalescer Elements

\begin{tabular}{|c|c|c|c|c|c|}
\hline \multirow{2}{*}{ Analyte } & \multicolumn{4}{|c|}{ 7-Day ICPES Sample Results (mg/L) } & \multirow{2}{*}{$\begin{array}{c}\text { Source } \\
\text { Material } \\
(\mathrm{mg} / \mathrm{L})\end{array}$} \\
\hline & A (coalescer) & B (pre-filter) & C (pre-filter) & D (pre-filter) & \\
\hline $\mathrm{Ag}$ & $<0.214$ & $<0.214$ & $<0.214$ & $<0.214$ & $<2.14$ \\
\hline $\mathrm{Al}$ & 995 & 1980 & 2090 & 1850 & 5290 \\
\hline $\mathrm{B}$ & 0.577 & 1.01 & 1.18 & 0.961 & 82.6 \\
\hline $\mathrm{Ba}$ & 1.24 & 1.62 & 2.08 & 1.72 & $<0.59$ \\
\hline $\mathrm{Be}$ & $<0.011$ & $<0.011$ & $<0.011$ & $<0.011$ & $<0.7$ \\
\hline $\mathrm{Ca}$ & 11.6 & 31.5 & 44 & 31.8 & 2.27 \\
\hline $\mathrm{Cd}$ & 3.17 & 4.14 & 5.24 & 4.15 & 1.17 \\
\hline $\mathrm{Ce}$ & $<0.66$ & $<0.66$ & $<0.66$ & $<0.66$ & $<6.6$ \\
\hline Co & 0.209 & 0.171 & 0.252 & 0.214 & \\
\hline $\mathrm{Cr}$ & 5.96 & 5.97 & 7.95 & 6.15 & 71.6 \\
\hline $\mathrm{Cu}$ & 2.42 & 2.75 & 4.06 & 2.52 & 1.68 \\
\hline $\mathrm{Fe}$ & 73.1 & 65.1 & 91.5 & 71.1 & 12.2 \\
\hline Gd & $<0.136$ & 0.187 & 0.216 & 0.172 & $<2.12$ \\
\hline $\mathrm{K}$ & 5.35 & 7.03 & 7.44 & 6.15 & 480 \\
\hline $\mathrm{La}$ & $<0.108$ & $<0.108$ & $<0.108$ & $<0.108$ & $<1$ \\
\hline $\mathrm{Li}$ & 2.4 & 4.18 & 6.52 & 4.38 & 25.6 \\
\hline $\mathrm{Mg}$ & 10.6 & 13.4 & 18.2 & 13.6 & $<0.25$ \\
\hline $\mathrm{Mn}$ & 1.21 & 1.14 & 1.52 & 1.12 & 0.88 \\
\hline Mo & $<0.626$ & $<0.626$ & $<0.626$ & $<0.626$ & 8.47 \\
\hline $\mathrm{Na}$ & 1340 & 3240 & 3480 & 3060 & 157000 \\
\hline $\mathrm{Ni}$ & 24.9 & 18.8 & 26 & 20 & $<2.35$ \\
\hline $\mathrm{P}$ & $<0.849$ & $<0.849$ & $<0.849$ & $<0.849$ & 272 \\
\hline $\mathrm{Pb}$ & $<0.731$ & $<0.731$ & $<0.731$ & $<0.731$ & $<7.31$ \\
\hline S & $<7.5$ & $<7.5$ & $<7.5$ & $<7.5$ & 2410 \\
\hline $\mathrm{Sb}$ & $<0.688$ & $<0.688$ & $<0.688$ & $<0.688$ & $<10.4$ \\
\hline $\mathrm{Si}$ & 708 & 255 & 276 & 252 & 168 \\
\hline Sn & $<0.429$ & $<0.429$ & 0.5 & $<0.429$ & $<4.29$ \\
\hline $\mathrm{Sr}$ & 0.115 & 0.207 & 0.267 & 0.201 & $<0.08$ \\
\hline Th & $<2.36$ & $<2.36$ & $<2.36$ & $<2.36$ & \\
\hline $\mathrm{Ti}$ & 335 & 592 & 762 & 594 & $<0.17$ \\
\hline $\mathrm{U}$ & 20.4 & 37.8 & 45.8 & 37.2 & $<44.5$ \\
\hline V & 0.091 & 0.189 & 0.232 & 0.194 & $<0.52$ \\
\hline $\mathrm{Zn}$ & 4.89 & 4.47 & 5.83 & 4.23 & 6.5 \\
\hline $\mathrm{Zr}$ & 0.617 & 0.98 & 1.18 & 0.977 & $<0.89$ \\
\hline
\end{tabular}

The analytical uncertainty for the ICPES samples is $10 \%$. 
Table 3. 14-Day ICPES Results for the Pre-filter and Coalescer Elements

\begin{tabular}{|c|c|c|c|c|c|}
\hline \multirow{2}{*}{ Analyte } & \multicolumn{4}{|c|}{ 14-Day ICPES Sample Results (mg/L) } & \multirow{2}{*}{$\begin{array}{c}\text { Source } \\
\text { Material } \\
(\mathrm{mg} / \mathrm{L})\end{array}$} \\
\hline & A (coalescer) & B (pre-filter) & C (pre-filter) & D (pre-filter) & \\
\hline Ag & $<0.214$ & $<0.214$ & $<0.214$ & $<0.214$ & $<2.14$ \\
\hline $\mathrm{Al}$ & 1000 & 2040 & 2120 & 1900 & 5290 \\
\hline $\mathrm{B}$ & 0.565 & 2.3 & 2.44 & 2.25 & 82.6 \\
\hline $\mathrm{Ba}$ & 1.31 & 6.72 & 8.42 & 12.7 & $<0.59$ \\
\hline $\mathrm{Be}$ & $<0.011$ & $<0.011$ & $<0.011$ & $<0.011$ & $<0.7$ \\
\hline $\mathrm{Ca}$ & 11.9 & 33 & 45.9 & 34.7 & 2.27 \\
\hline $\mathrm{Cd}$ & 3.19 & 4.16 & 5.24 & 4.18 & 1.17 \\
\hline $\mathrm{Ce}$ & $<0.66$ & $<0.66$ & $<0.66$ & $<0.66$ & $<6.6$ \\
\hline Co & 0.241 & 0.187 & 0.291 & 0.193 & \\
\hline $\mathrm{Cr}$ & 6.33 & 6.16 & 8.13 & 6.29 & 71.6 \\
\hline $\mathrm{Cu}$ & 2.48 & 2.79 & 4.12 & 2.5 & 1.68 \\
\hline $\mathrm{Fe}$ & 78.8 & 68.1 & 96 & 74.5 & 12.2 \\
\hline $\mathrm{Gd}$ & $<0.136$ & 0.187 & 0.201 & 0.161 & $<2.12$ \\
\hline $\mathrm{K}$ & 3.83 & 12.8 & 12.6 & 14.4 & 480 \\
\hline $\mathrm{La}$ & $<0.108$ & $<0.108$ & $<0.108$ & $<0.108$ & $<1$ \\
\hline $\mathrm{Li}$ & 2.57 & 4.2 & 6.63 & 4.43 & 25.6 \\
\hline $\mathrm{Mg}$ & 10.9 & 13.7 & 18.5 & 14 & $<0.25$ \\
\hline $\mathrm{Mn}$ & 1.28 & 1.17 & 1.57 & 1.16 & 0.88 \\
\hline Mo & $<0.626$ & $<0.626$ & $<0.626$ & $<0.626$ & 8.47 \\
\hline $\mathrm{Na}$ & 1360 & 3370 & 3550 & 3170 & 157000 \\
\hline $\mathrm{Ni}$ & 26.2 & 19.3 & 26.8 & 20.8 & $<2.35$ \\
\hline $\mathrm{P}$ & $<0.849$ & $<0.849$ & $<0.849$ & $<0.849$ & 272 \\
\hline $\mathrm{Pb}$ & $<0.731$ & $<0.731$ & $<0.731$ & $<0.731$ & $<7.31$ \\
\hline $\mathrm{S}$ & $<7.5$ & $<7.5$ & $<7.5$ & $<7.5$ & 2410 \\
\hline $\mathrm{Sb}$ & $<0.688$ & $<0.688$ & $<0.688$ & $<0.78$ & $<10.4$ \\
\hline $\mathrm{Si}$ & 688 & 54.4 & 54.5 & 73.4 & 168 \\
\hline Sn & $<0.429$ & $<0.429$ & $<0.429$ & $<0.429$ & $<4.29$ \\
\hline $\mathrm{Sr}$ & 0.116 & 0.224 & 0.286 & 0.248 & $<0.08$ \\
\hline Th & $<2.36$ & $<2.36$ & $<2.36$ & $<2.36$ & \\
\hline $\mathrm{Ti}$ & 344 & 607 & 769 & 612 & $<0.17$ \\
\hline $\mathrm{U}$ & 20.1 & 38.6 & 45.9 & 37.8 & $<44.5$ \\
\hline $\mathrm{V}$ & 0.077 & 0.198 & 0.222 & 0.169 & $<0.52$ \\
\hline $\mathrm{Zn}$ & 5.09 & 7.17 & 8.87 & 8.16 & 6.5 \\
\hline $\mathrm{Zr}$ & 0.651 & 1.04 & 1.23 & 1.04 & $<0.89$ \\
\hline
\end{tabular}

The analytical uncertainty for the ICPES samples is $10 \%$. 
SRNL-STI-2011-00513

Revision 0

Table 4. 28-Day ICPES Results for the Pre-filter and Coalescer Elements

\begin{tabular}{|c|c|c|c|c|c|}
\hline \multirow{2}{*}{ Analyte } & \multicolumn{4}{|c|}{ 28-Day ICPES Sample Results (mg/L) } & \multirow{2}{*}{$\begin{array}{c}\text { Source } \\
\text { Material } \\
(\mathrm{mg} / \mathrm{L})\end{array}$} \\
\hline & A (coalescer) & B (pre-filter) & C (pre-filter) & D (pre-filter) & \\
\hline $\mathrm{Ag}$ & $<0.146$ & $<0.146$ & $<0.146$ & $<0.146$ & $<2.14$ \\
\hline $\mathrm{Al}$ & 1010 & 2030 & 2080 & 2000 & 5290 \\
\hline $\mathrm{B}$ & $<0.952$ & $<0.952$ & $<0.952$ & $<0.952$ & 82.6 \\
\hline $\mathrm{Ba}$ & 1.4 & 1.73 & 2.23 & 2.03 & $<0.59$ \\
\hline $\mathrm{Be}$ & $<0.03$ & $<0.03$ & $<0.03$ & $<0.03$ & $<0.7$ \\
\hline $\mathrm{Ca}$ & 12.4 & 32.6 & 45.4 & 37 & 2.27 \\
\hline $\mathrm{Cd}$ & 3.34 & 4.35 & 5.53 & 4.89 & 1.17 \\
\hline $\mathrm{Ce}$ & $<0.427$ & $<0.427$ & $<0.427$ & $<0.427$ & $<6.6$ \\
\hline Co & 0.265 & 0.216 & 0.305 & 0.255 & \\
\hline $\mathrm{Cr}$ & 6.73 & 6.55 & 8.77 & 7.57 & 71.6 \\
\hline $\mathrm{Cu}$ & 2.45 & 2.71 & 4.12 & 2.84 & 1.68 \\
\hline $\mathrm{Fe}$ & 83.7 & 71.4 & 103 & 87.8 & 12.2 \\
\hline Gd & $<0.215$ & $<0.215$ & 0.241 & $<0.215$ & $<2.12$ \\
\hline $\mathrm{K}$ & 8.87 & 9.05 & 8.45 & 7.45 & 480 \\
\hline $\mathrm{La}$ & $<0.067$ & $<0.067$ & $<0.067$ & $<0.067$ & $<1$ \\
\hline $\mathrm{Li}$ & 2.49 & 4.2 & 6.52 & 4.82 & 25.6 \\
\hline $\mathrm{Mg}$ & 11 & 13.2 & 18.1 & 14.9 & $<0.25$ \\
\hline $\mathrm{Mn}$ & 1.38 & 1.24 & 1.69 & 1.39 & 0.88 \\
\hline Mo & $<0.617$ & $<0.617$ & $<0.617$ & $<0.617$ & 8.47 \\
\hline $\mathrm{Na}$ & 1360 & 3370 & 3540 & 3220 & 157000 \\
\hline $\mathrm{Ni}$ & 26.3 & 19.5 & 27.5 & 23.5 & $<2.35$ \\
\hline $\mathrm{P}$ & $<1.73$ & $<1.73$ & $<1.73$ & $<1.73$ & 272 \\
\hline $\mathrm{Pb}$ & $<0.716$ & $<0.716$ & $<0.716$ & $<0.716$ & $<7.31$ \\
\hline S & $<7.5$ & $<7.5$ & $<7.5$ & $<7.5$ & 2410 \\
\hline $\mathrm{Sb}$ & $<1.35$ & $<1.35$ & $<1.35$ & $<1.35$ & $<10.4$ \\
\hline $\mathrm{Si}$ & 25.3 & 22.2 & 20.2 & 23.2 & 168 \\
\hline Sn & $<0.561$ & $<0.561$ & $<0.561$ & $<0.561$ & $<4.29$ \\
\hline $\mathrm{Sr}$ & 0.121 & 0.212 & 0.272 & 0.229 & $<0.08$ \\
\hline Th & $<1.07$ & $<1.07$ & $<1.07$ & $<1.07$ & \\
\hline $\mathrm{Ti}$ & 349 & 614 & 768 & 636 & $<0.17$ \\
\hline $\mathrm{U}$ & 19.2 & 35.5 & 43.3 & 38.4 & $<44.5$ \\
\hline V & $<0.39$ & $<0.39$ & $<0.39$ & $<0.39$ & $<0.52$ \\
\hline $\mathrm{Zn}$ & 5.22 & 4.83 & 6.49 & 5.03 & 6.5 \\
\hline $\mathrm{Zr}$ & 0.684 & 1.13 & 1.36 & 1.24 & $<0.89$ \\
\hline
\end{tabular}

The analytical uncertainty for the ICPES samples is $10 \%$. 
The “source material” results are from the ICPES macrobatch 3 feed solution samples.

An examination of the results shows that there is no time dependency on the results except for silicon. To more clearly show this, see Table 5. In Table 5, we present sample results for the most important analytes ( $\mathrm{Al}, \mathrm{Na}, \mathrm{Si}, \mathrm{Ti}, \mathrm{U}$ ) for all four elements. The same exercise holds true for all the analytical results, but the trend is most clear in the five previously listed analytes.

Table 5. Selected ICPES Results

\begin{tabular}{|c|c|c|c|c|}
\hline \multicolumn{5}{|c|}{ Element A (coalescer) } \\
\hline Analyte & 1 d result & $7 d$ result & 14 d result & 28 d result \\
\hline $\mathrm{Al}$ & 990 & 995 & 1000 & 1010 \\
\hline $\mathrm{Na}$ & 1310 & 1340 & 1360 & 1360 \\
\hline $\mathrm{Si}$ & 787 & 708 & 688 & 25.3 \\
\hline $\mathrm{Ti}$ & 322 & 335 & 344 & 349 \\
\hline $\mathrm{U}$ & 20.3 & 20.4 & 20.1 & 19.2 \\
\hline \multicolumn{5}{|c|}{ Element B (pre-filter) } \\
\hline $\mathrm{Al}$ & 2080 & 1980 & 2040 & 2030 \\
\hline $\mathrm{Na}$ & 3330 & 3240 & 3370 & 3370 \\
\hline $\mathrm{Si}$ & 1540 & 255 & 54.4 & 22.2 \\
\hline $\mathrm{Ti}$ & 605 & 592 & 607 & 614 \\
\hline $\mathrm{U}$ & 41.2 & 37.8 & 38.6 & 35.5 \\
\hline \multicolumn{5}{|c|}{ Element C (pre-filter) } \\
\hline $\mathrm{Al}$ & 2170 & 2090 & 2120 & 2080 \\
\hline $\mathrm{Na}$ & 3530 & 3480 & 3550 & 3540 \\
\hline $\mathrm{Si}$ & 1610 & 276 & 54.5 & 20.2 \\
\hline $\mathrm{Ti}$ & 782 & 762 & 769 & 768 \\
\hline $\mathrm{U}$ & 51.0 & 45.8 & 45.9 & 43.3 \\
\hline \multicolumn{5}{|c|}{ Element D (pre-filter) } \\
\hline $\mathrm{Al}$ & 1970 & 1850 & 1900 & 2000 \\
\hline $\mathrm{Na}$ & 3170 & 3060 & 3170 & 3220 \\
\hline $\mathrm{Si}$ & 1440 & 252 & 73.4 & 23.2 \\
\hline $\mathrm{Ti}$ & 616 & 594 & 612 & 636 \\
\hline $\mathrm{U}$ & 41.8 & 37.2 & 37.8 & 38.4 \\
\hline
\end{tabular}

Table 5 clearly shows that there is little effect of the leaching time on the results except for silicon.

The silicon results are markedly different from the other analytes. All the filter/coalescer elements show a marked decline in silicon concentration over time. The decline in 
silicon ranges from 97-99\% of the original values. This would suggest either that the silicon containing solids are initially dissolving, and then precipitating, or that the silicon containing compounds are not dissolving, but being "shaken off" the elements during the initial immersion into the leaching acid and remaining as fine undissolved solids that are initially evenly dispersed into solution, and then gradually sinking to the bottom of the bottle where they are not sampled.

Pre-filter vs. Coalescer Element Results: There is a significant ( 50\%) difference in some of the pre-filer Elements (B, C, D) dissolved species compared to the coalescer (Element $\mathrm{A}$ ) results. In particular, $\mathrm{Al}, \mathrm{Na}, \mathrm{Si}, \mathrm{Ti}$ and $\mathrm{U}$ show appreciably higher concentrations on the pre-filter as compared to the coalescer. Table 6 shows the time averaged $(1,7,14$, and 28 day) sample results for selected elements.

\section{Table 6. Averaged Selected ICPES Results for the Pre-filter and Coalescer Elements}

\begin{tabular}{|c|c|c|c|c|}
\hline \multirow{2}{*}{ Analyte } & \multicolumn{4}{|c|}{ Averaged ICPES Sample Results (mg/L) } \\
\cline { 2 - 5 } & $\begin{array}{c}\text { A (coalescer) } \\
\text { Average }\end{array}$ & $\begin{array}{c}\text { B (pre-filter) } \\
\text { Average }\end{array}$ & $\begin{array}{c}\text { C (pre-filter) } \\
\text { Average }\end{array}$ & $\begin{array}{c}\text { D (pre-filter) } \\
\text { Average }\end{array}$ \\
\hline $\mathrm{Al}$ & 999 & 2030 & 2115 & 1930 \\
\hline $\mathrm{Na}$ & 1340 & 3330 & 3525 & 3160 \\
\hline $\mathrm{Si} *$ & 787 & 1540 & 1610 & 1440 \\
\hline $\mathrm{Ti}$ & 338 & 605 & 770 & 615 \\
\hline $\mathrm{U}$ & 20.0 & 38.3 & 46.5 & 38.8 \\
\hline
\end{tabular}

* For the purpose of this comparison, we only use the 1 hour data point for the silicon instead of the average, due to the marked decline in silicon over time. We believe that the 1 hour data point represents the maximum or close to the maximum silicon from the pre-filter or coalescer elements.

The analytes shown in Table 6 represent species that are either part of previously noted solids fouling (e.g., sodium aluminosilicates), or possess the chemistry to be in solid form as individual oxides (U, Ti). Except for sodium, all the analytes show a $\sim 2 x$ increase from the coalescer to pre-filter results. The sodium increase is $\sim 2.5 \mathrm{x}$, but this may be due to the presence of the high sodium-containing decontaminated salt solution. The service life of the coalescer was $\sim 1 / 3$ of the pre-filters, and so would be expected to accumulate fewer solids; however, the coalescer was also downstream of the pre-filters, and thus should accumulate less bulk solids if the pre-filters were doing their job. In total, we expect fewer solids on the coalescer.

High Titanium Results: While SRNL has leached and analyzed coalescer elements ${ }^{1}$ and parts of the Actinide Removal process guard filter before, ${ }^{2}$ the current results show that far more titanium in the leaching samples that can be from the feed material. Considering there is less-than detectable amounts of $\mathrm{Ti}$ in the feed material, the titanium must be from 
monosodium titanate (MST). The MST fines must be passing through the filters at ARP and ending up caught on the pre-filters and coalescer, or the MST is dissolving at ARP, and precipitating in the MCU system to get caught on the pre-filters and coalescer. SRNL is currently studying the ability of caustic solutions to dissolve MST solids and will report on this shortly.

In a previous document ${ }^{2}$ on the analysis of the ARP guard filter, SRNL was able to estimate the amount of MST solids passing through the primary ARP filter by knowing the amount of solution that passed through the filter, and estimating the mass of MST solids loading on the guard filter. In that case, we were able to estimate $~ 6.5$ grams of MST solids on entire guard filter, from passing 200,000 gallons of salt solution (which required the use of $\sim 303 \mathrm{~kg}$ of MST). The $6.5 \mathrm{~g}$ of MST "bleed through" represented $\sim 0.0021 \%$ of the MST or an MST concentration in the filtrate of $\sim 0.01 \mathrm{mg} / \mathrm{L}$. These solids presumably exist as fines that pass through the smaller $(0.1 \mu$ nominal $)$ pore-size cross flow filter, penetrate into the larger $(0.5 \mu \mathrm{m}$ nominal $)$ pores of the guard filter and become trapped either due to lower pressure differential available to force flow or for other reasons, such as coagulation of interstitial MST solids. While SRNL has observed and anticipates MST-filter bleed through, ${ }^{3}$ we have not quantified the extent to date.

With regard to the pre-filters and coalescers described in this document, we can perform the same type of calculation. The pre-filters and coalescer collectively passed $\sim 4,700,000 \mathrm{~L}$ of salt solution at time of removal from processing. ${ }^{r}$ From the leaching data, we calculate that $\sim 50 \mathrm{~g}$ of MST was captured on the pre-filters and coalescers. 50 grams represents $0.00268 \%$ of all the MST added during those 4,700,000 L of salt solution, or an MST concentration of $\sim 0.011 \mathrm{mg} / \mathrm{L}$. These numbers for the pre-filters and coalescer are curiously close to the values calculated from the ARP guard filter, and may provide further information on the nature of the bleed through; however, further consideration and analysis is warranted.

Trends Discerned from other Analytes: For the rest of the results, we can derive further information. Analytes that give approximately the same results over time, and between the pre-filter and coalescer results, are probably due to materials that are in solution, or are extremely fine solids. Examples of these analytes are $\mathrm{Cd}, \mathrm{Co}, \mathrm{Cr}, \mathrm{Cu}, \mathrm{Fe}, \mathrm{K}, \mathrm{Mn}, \mathrm{Ni}$, Zn, and Zr.

3.3 FTIR XRD Analyses Samples cut from the pre-filters and from the coalescer were delivered for $\mathrm{XRD}$ analysis. Figure 3 is the XRD spectra from the coalescer (Element A), and Figure 4 is from Element C. XRD analyses of Elements B and D gave the same

\footnotetext{
${ }^{\Upsilon_{T}}$ The coalescer contacted only $\sim 1 / 3$ of the volume of salt solution as the pre-filters. Therefore, for the purpose of this calculation, we scale up the MST captured by the coalescer by a factor of three. Under this assumption, this means that the coalescer is effectively capturing more solids than each of the individual pre-filters.
} 
result as Element $\mathrm{C}$. The coalescer material is polyphenylene sulfide (Ryton) and is crystalline enough to show up on XRD.

Figure 3. XRD Results from Element A (Coalescer)

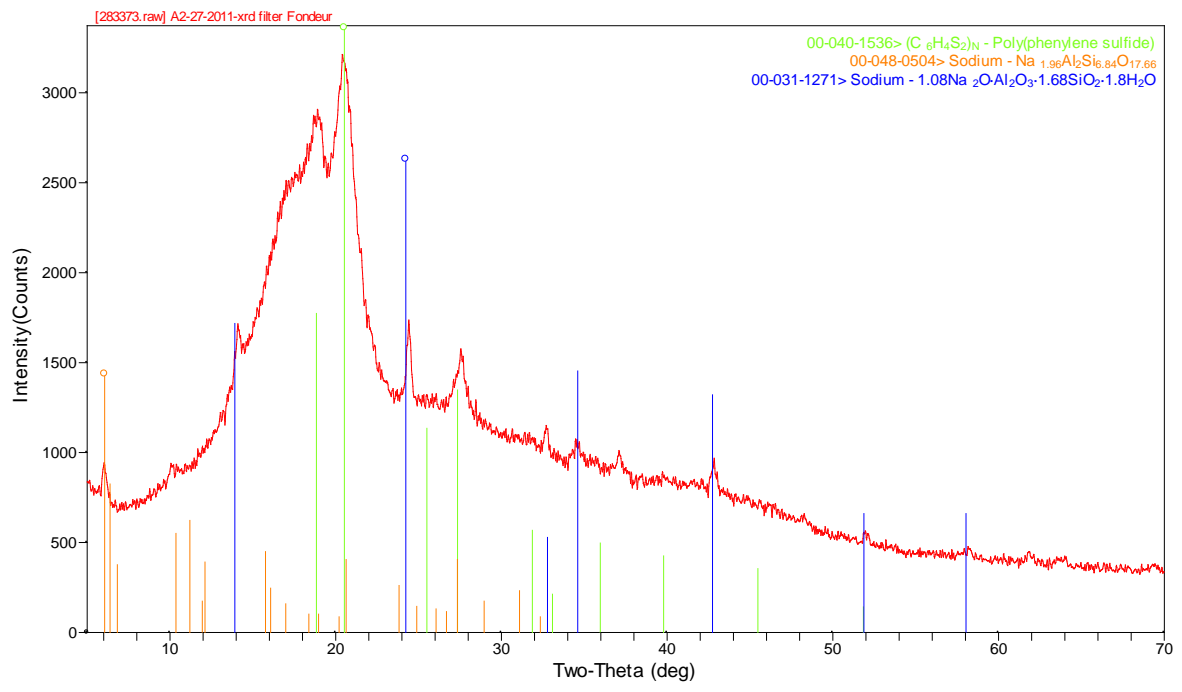

Figure 4. XRD Results from Element C (Pre-filter)

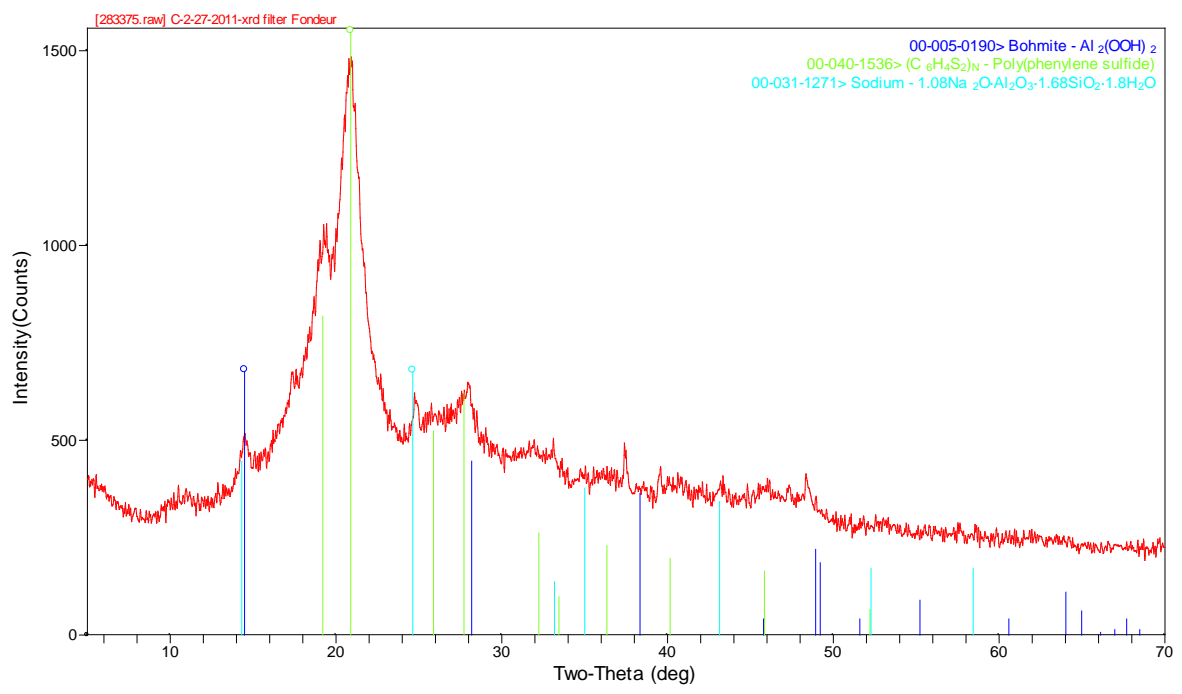


The XRD analysis shows solids identified in earlier XRD samples of previous coalescers - aluminosilicates and aluminum solids. ${ }^{4}$ The titanium and uranium containing solids must be in an amorphous state - or, in the case of uranium, in low concentration - and are not detectable by XRD.

3.4 SEM Analyses Samples of the pre-filters and coalescer were delivered for SEM analysis. SEM allows element identification on points. Figure 5 is the first SEM for a sample from the coalescer (Element A).

Figure 5. SEM of Coalescer Sample

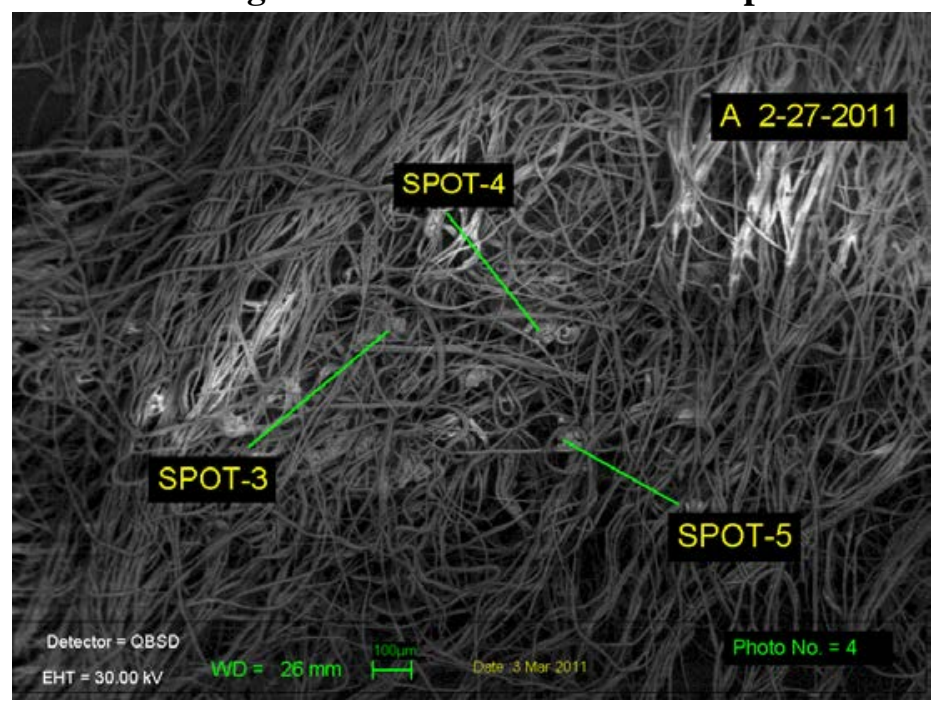

The spaghetti-like strings are Ryton fibers. The SEM can scan the bulk material for elemental breakdown. Spot 3, -4 , and -5 are various solids that were captured on the Ryton. Once a spot of interest in located, the detailed elemental breakdown of that small area can be found (as in Figure 6). Note the absence of Pu, U and Sr despite a high relative concentration of Ti. This would suggest the Ti may not be MST fines but rather precipitated Ti that leached from the MST in the process.

Figure 6. SEM of Deposited Solids

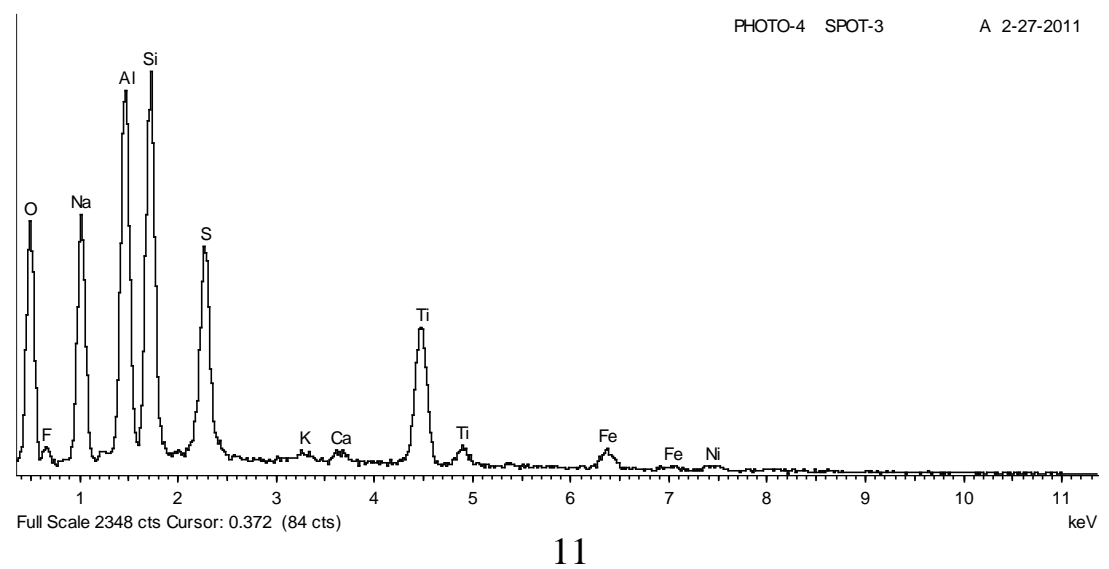


The deposited solids in Spot 3 contain the same elements identified in the XRD (Figure 3) or in the leachate samples from the coalescer (Table 5). SEM can zoom in on a spot to see if there is a heterogeneous distribution of elements in the solids (Figure 7). (Note that the solid does not resemble the shape and appearance of MST.)

\section{Figure 7. Closer View SEM of Spot 3}

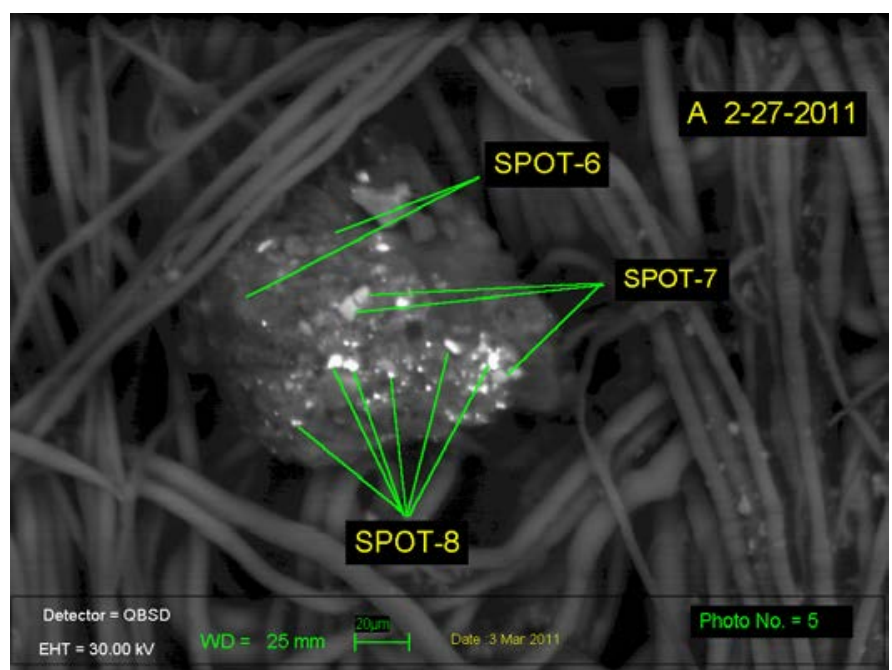

In this case, a closer look at Spot 3 provides an elemental breakdown (Figure 8).

\section{Figure 8. SEM of Spot-8 from the Previous Figure}

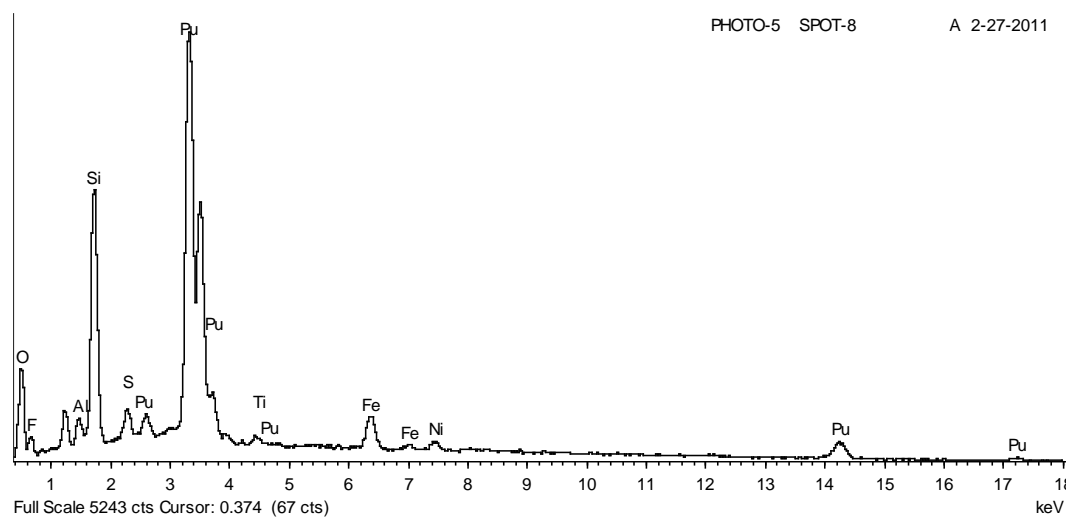

Note that there is no strong correlation between the plutonium and the titanium in these solids. This scan shows a relatively high concentration of $\mathrm{Pu}$ with much lower mass 
loadings of Ti. For MST-bound Pu, one expects a high Ti to Pu ratio; the opposite of what is observed. There is no bulk association of the type that one would associate with sorption of plutonium on the MST (presumably the Ti is from MST).

Figure 9 is the first SEM for a sample from a pre-filter element (Element B).

Figure 9. SEM of pre-filter Sample

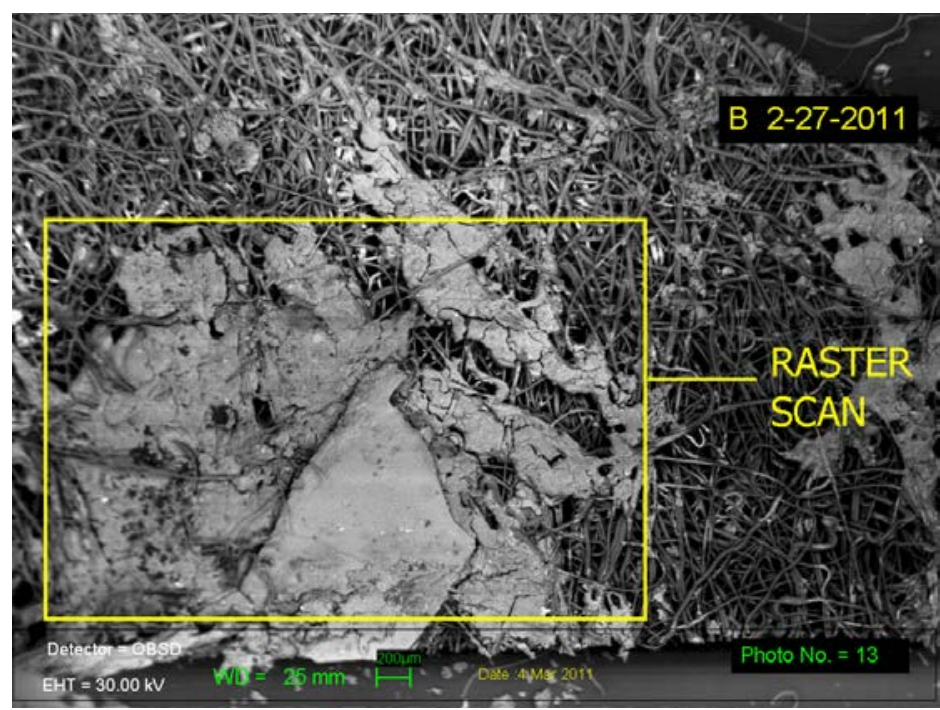

The spaghetti-like strings are Ryton fibers. The SEM can scan the deposited material for elemental breakdown (as in Figure 10).

Figure 10. SEM of Deposited Solids

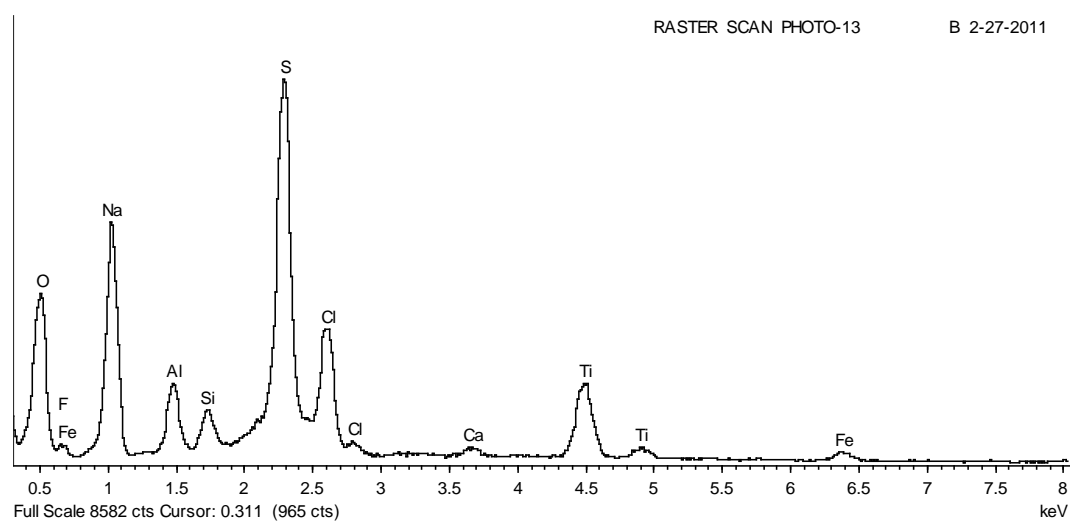


The deposited solids contain the same elements identified in the XRD (Figure 3) or in the leachate samples from the coalescer (Table 5). Figure 11 depicts an SEM from zooming into a spot to see if there is a heterogeneous distribution of elements in the solids.

Figure 11. Closer View SEM

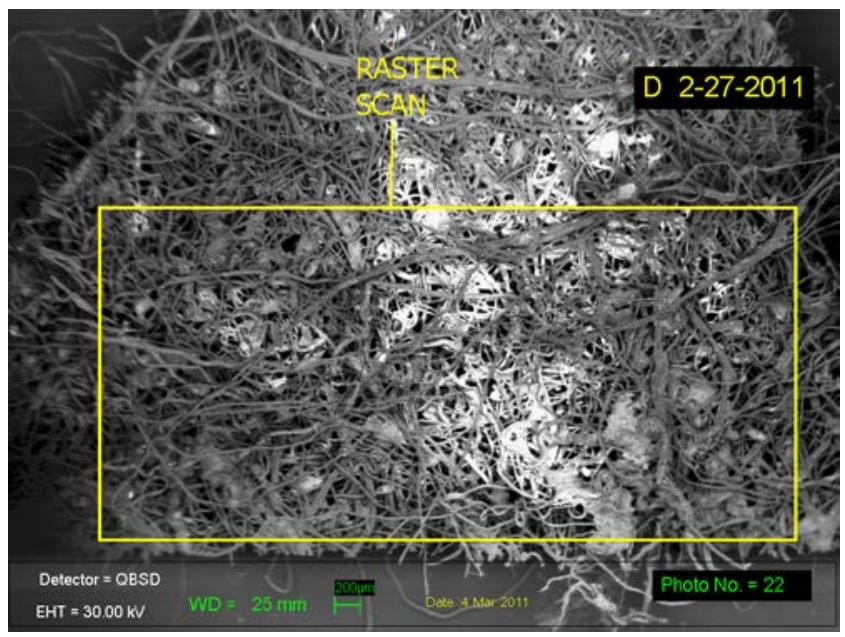

In this case, a closer look at Spot 3 provides an elemental breakdown (Figure 12).

Figure 12. SEM of Closer View from the Previous Figure

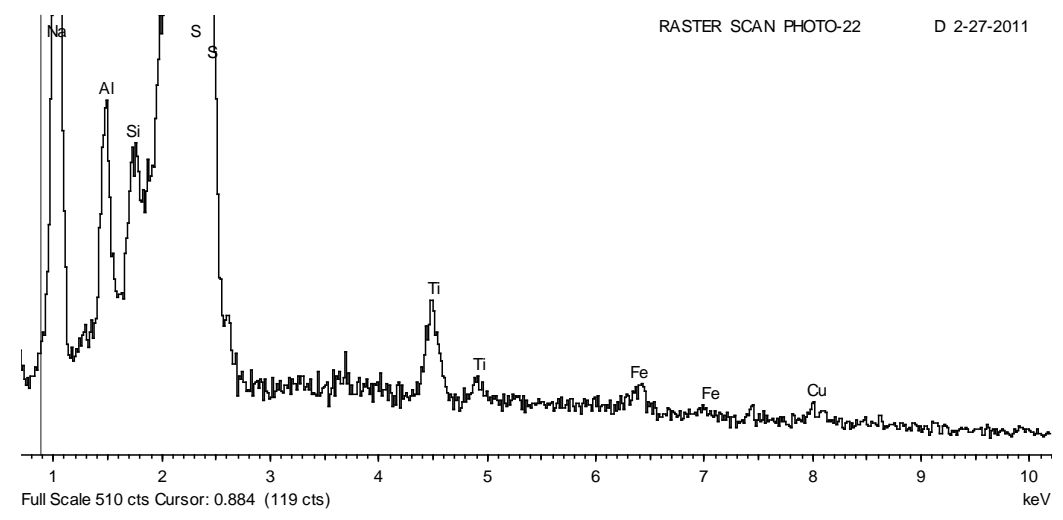

This scan indicates no presence of Pu with the Ti; again suggesting the deposited material is not MST fines but rather precipitated Ti from leaching of MST. 


\section{$\underline{3.5 \text { FTIR and Visual Microscopy }}$}

SRNL analyzed sections of the pre-filters and coalescers using a combination of visual microscopy and FTIR. Figure 13 is the optical microscopy from a section of the coalescer (Element A).

Figure 13. Optical Microscopy from the Coalescer

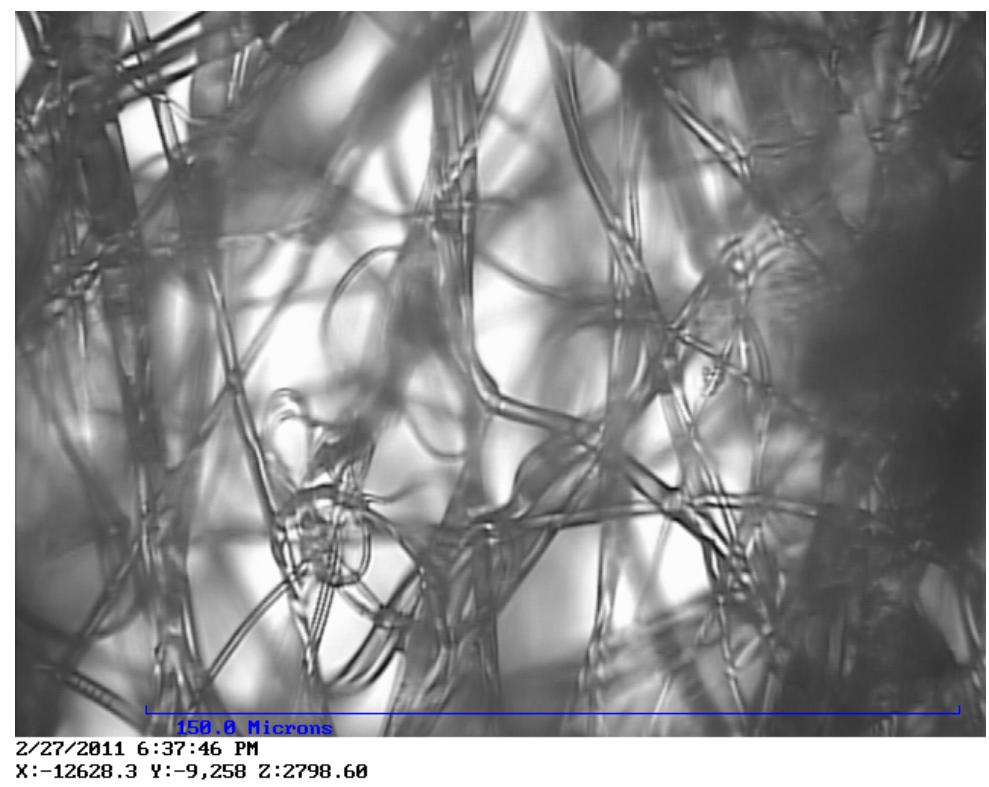

The microscopy of the sample showed relatively light fouling. There are no large pockets of solids, or bridges between the fibers. Using FTIR, we can examine roughly the same area to determine which compounds are present (Figure 14).

Figure 14. FTIR of the Coalescer Sample

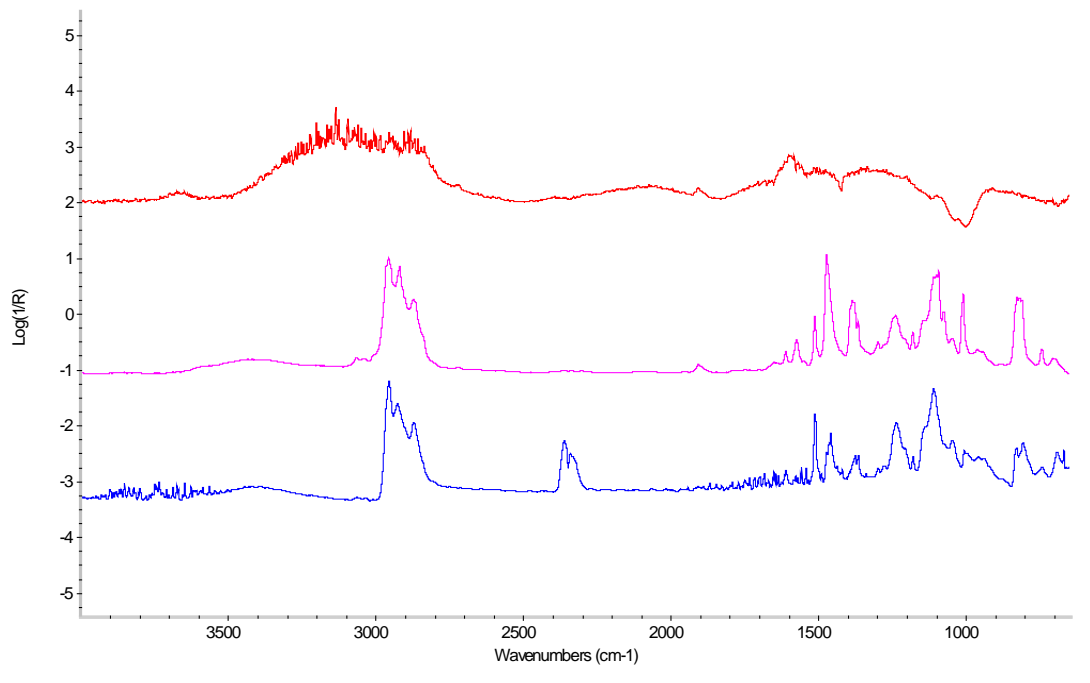


Figure 14 shows three different FTIR spectra. The middle, purple spectra is from the coalescer sample. The top, red, spectrum is from aluminosilicate solids from a different sample, and the bottom, blue spectrum is from a different solvent sample. The top and bottom spectra are used for comparison. The coalescer sample shows solvent and Ryton $^{\mathrm{TM}}$ and a small peak at $1900 \mathrm{~cm}^{-1}$ from the aluminosilicate solids.

After further examination, a section containing light solids fouling was located (Figure 15).

Figure 15. Further Optical Microscopy of the Coalescer Sample

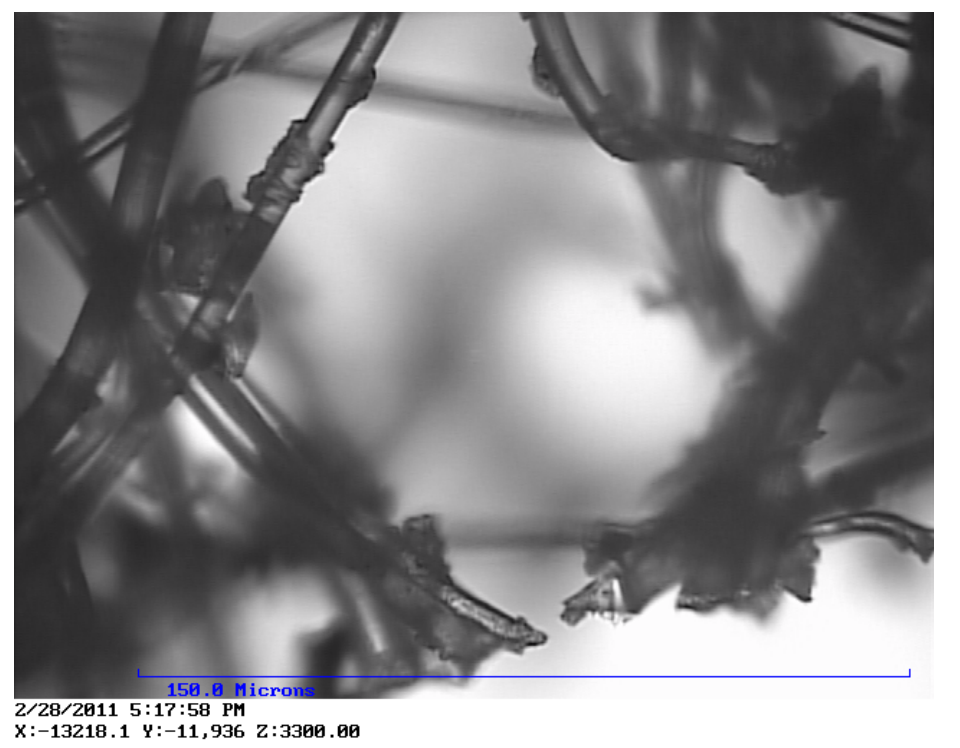

Unlike the area shown in Figure 13, we can now see some evidence of solids. This is an indication that solids are infrequently present and the coalescer does not show uniform (even light) fouling. The shape of the solids in Figure 15 suggests a mixture of impacting particulates and nucleation, although the overall solid loading is still fairly light. Again, these particulates do not resemble MST fines in shape and appearance.

A FTIR examination of roughly the same area, with a focus on a section of solids, shows evidence of aluminosilicates (Figure 16). The background of Ryton ${ }^{\mathrm{TM}}$ is omitted for clarity. 


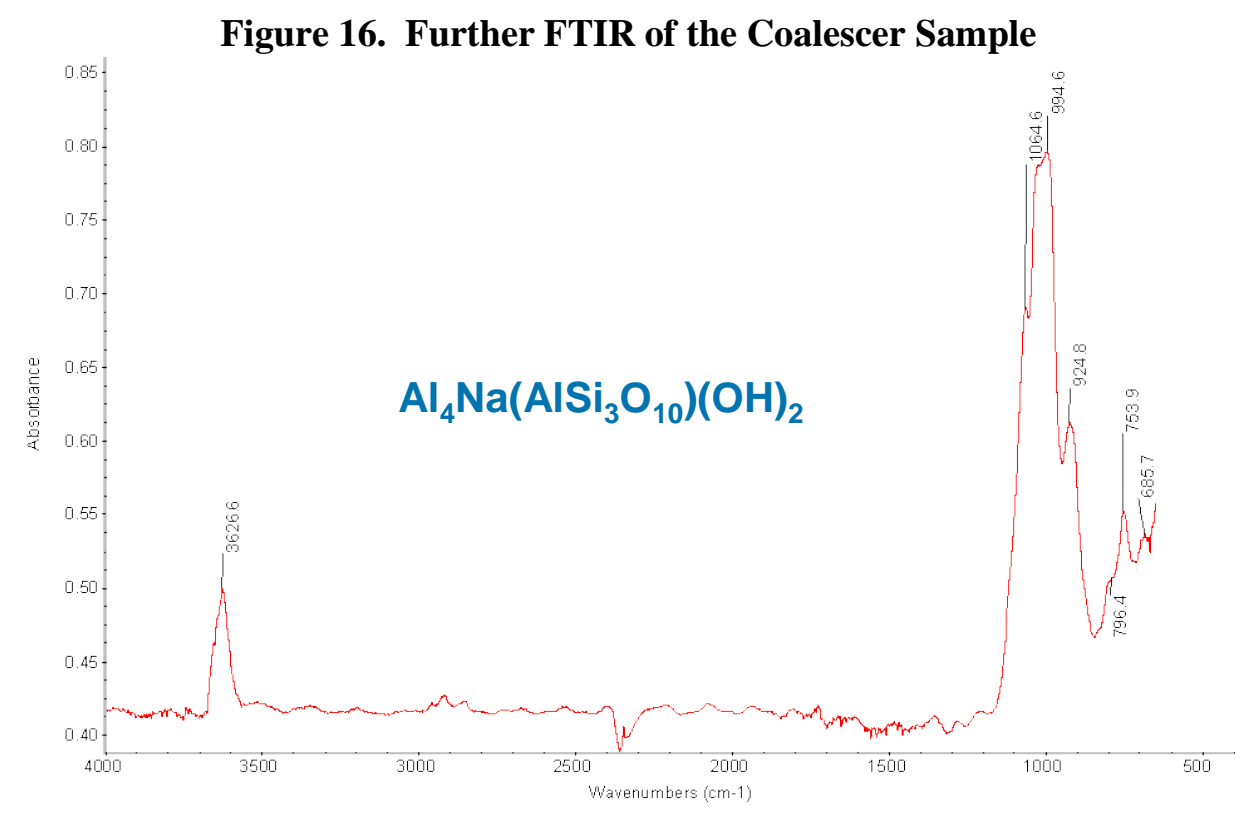

Samples from all three pre-filter elements were examined by optical microscopy (Figure 17).

Figure 17. Optical Microscopy of all Pre-filters

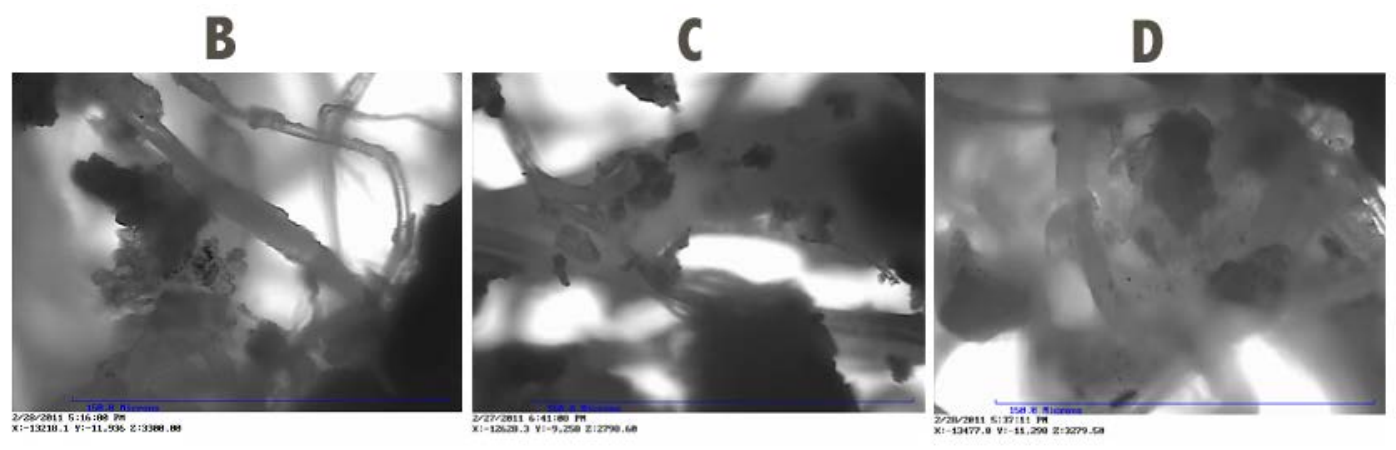

In each case we noted the same approximate observations. Moderate fouling was evident, with the particle morphology being indicative of trapping being the predominant trapping method, rather than nucleation. The particulates do not resemble MST fines in shape or appearance. 
SRNL also performed FTIR analysis on all three pre-filters, giving the same approximate results. For comparison purposes, Figure 18 shows FTIR spectra of the coalescer/prefilters and several reference compounds.

The top, dark green trace, is from Pre-filter (Element B). The second from top, red trace, is typical for Coalescer (A) and Pre-filter (C and D). The other traces are references for different materials that might have been in the feed material. Frit is the material used in DWPF glass pouring and is a borosilicate material. ${ }^{5}$

It is evident that the analysis of the coalescer and pre-filters $\mathrm{C}$ and $\mathrm{D}$ indicate the presence of aluminosilicates ( 925 to $1050 \mathrm{~cm}^{-1}$ ) and a small amount of hydrated MST $\left(\sim 1650 \mathrm{~cm}^{-1}\right)$. We do not find evidence of oxalates. Pre-filter B gives much the same result, but with the addition of borosilicate frit (borosilicates, at $\sim 1420 \mathrm{~cm}^{-1}$ ). There is no particular increase in boron or silicon values in the leached element $\mathrm{B}$, so the amount of borosilicates in element B must be relatively small or localized. 
Figure 18. Comparison of FTIR Spectra

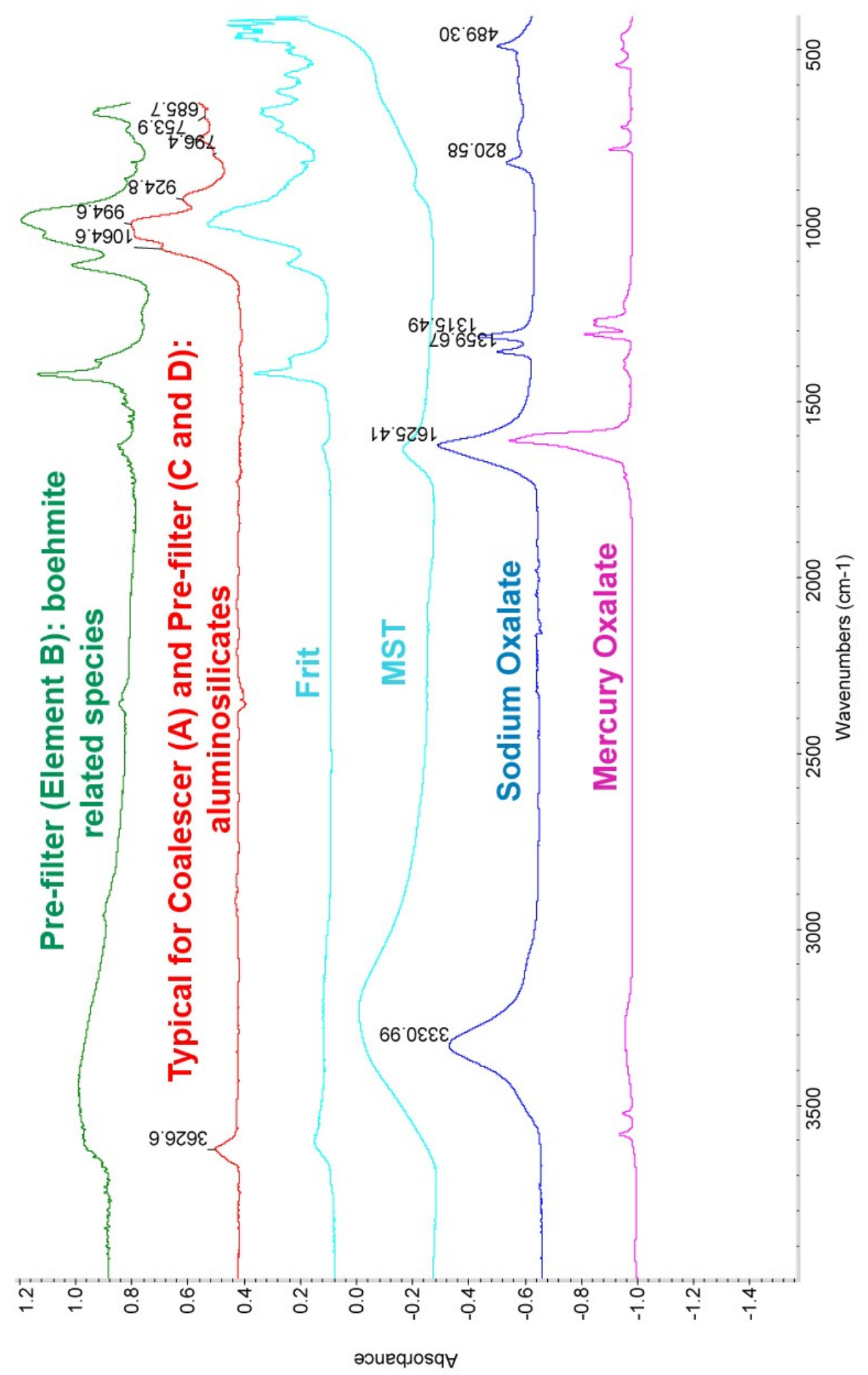


SRNL-STI-2011-00513

Revision 0

\subsection{Conclusions}

After analyzing the three pre-filer elements and the coalescer element, performing leaching studies and various analyses on all 4, we arrive at the following conclusions.

- The three pre-filter elements give similar results when analyzed. Pre-filter B has additional solids in the form of borosilicates, but the quantity must be low, given the low boron results of the leaching studies.

- The coalescer gives essentially the same qualitative results as the pre-filters, with the pre-filters having 2-3 times the concentration of those elements associated with common solids (Al, Na, Si, Ti, U). This would be consistent with the function of the prefilters - removal of most of the solids from solution.

- The solids that were retained on the elements by mass largely consist of aluminum, sodium, silicon, and titanium oxide/hydroxides. The first three elements are typically associated with aluminosilicate solids, which we have explicitly identified via XRD and FTIR. These types of solids have been routinely observed on analyzed DSS coalescers in the past. This is the first time we have reported titanium solids in this magnitude being present on a coalescer or pre-filter.

- From leaching data, the coalescer is retaining about half as much solids as each of the pre-filter elements. Given that the coalescer has only passed $~ 1 / 3$ as much salt solution as the pre-filter elements (from the duration of use), this implies the coalescer is better at retaining solids (given equal flow through) than any one of the individual pre-filter elements. This is counter-intuitive given that the coalescer is in series downstream from the pre-filters.

- Overall, the analyses indicate that there is no strong, or heavy fouling of any of the elements. Both trapping and nucleation of solids have been noted. A Kozeny-Carman analysis of the fouling should be considered for future work to see if we can corroborate the pressure drop with the degree of visible particle fouling.

- Given the fact that the pre-filters and coalescer have passed $\sim 4,700,000 \mathrm{~L}$ and $\sim 1,544,000$ L respectively, we can say that they have performed within expectations. 


\subsection{References}

${ }^{1}$ Peters, T. B. , Fondeur, F. F. , Fink, S. D.,” Diagnostic Analyses of the Decontaminated Salt Solution Coalescers from Initial Radiological Operations of the Modular Caustic-side Solvent Extraction Unit”, SRNL-STI-2008-00369, Rev. 0, October 12, 2008.

${ }^{2}$ Peters, T. B. , Fondeur, F. F. , Fink, S. D., "Results from Analysis of Actinide Removal Process Guard Filter”, SRNL-STI-2009-00456, Rev. 1, January 27, 2010.

3 M .R. Poirier, T. M. Jones, S. D. Fink, "Evaluation of Mott Filter Performance: Solids Removal Efficiency”, WSRC-TR-2002-00256, May 30, 2002.

${ }^{4}$ Peters, T. B. , Fondeur, F. F. , Fink, S. D., "Results from Analysis of the First and Second Strip Effluent Coalescer Elements from Radioactive Operations of the modular Caustic-Side Solvent Extraction Unit”, SRNL-STI-2010-00088, Rev. 0, June 2011.

${ }^{5}$ J. W. Ray, B. H. Culbertson, S. L. Marra, C. M. Jantzen, T. B. Edwards, “Technical Bases for the DWPF Glass Product Control Program”, WSRC-IM-91-116-5, Revision 3, March 2006. 


\section{Distribution:}

\section{E. J. Freed, 704-56H}

D. J. Martin, 241-152H

M. W. Geeting, 241-152H

B. A. Gifford, 704-56H

S. P. McLeskey, 241-152H

B. A. Oard, 241-197H

R. E. Edwards, Jr., 773-67A

K. D. Harp, 766-H

K. L. Lang, 241-152H

S. L. Marra, 773-A

C. C. Herman, 99-W

B. J. Giddings, 786-5A

F. M. Pennebaker, 773-42A

T.B. Peters, 773-42A

C. A. Nash, 773-42A

M. R. Poirier, 773-42A

F. F. Fondeur, 773-A

R. A. Pierce, 773-A

K. M. Fox, 999-W

R. K. Leugemors, 992-5W

W. B. Brasel, 992-2W

C. Conner, Parsons

R. Lentsch, Parsons

P.C. Suggs, 704-S

P. R. Jackson, 703-46A 